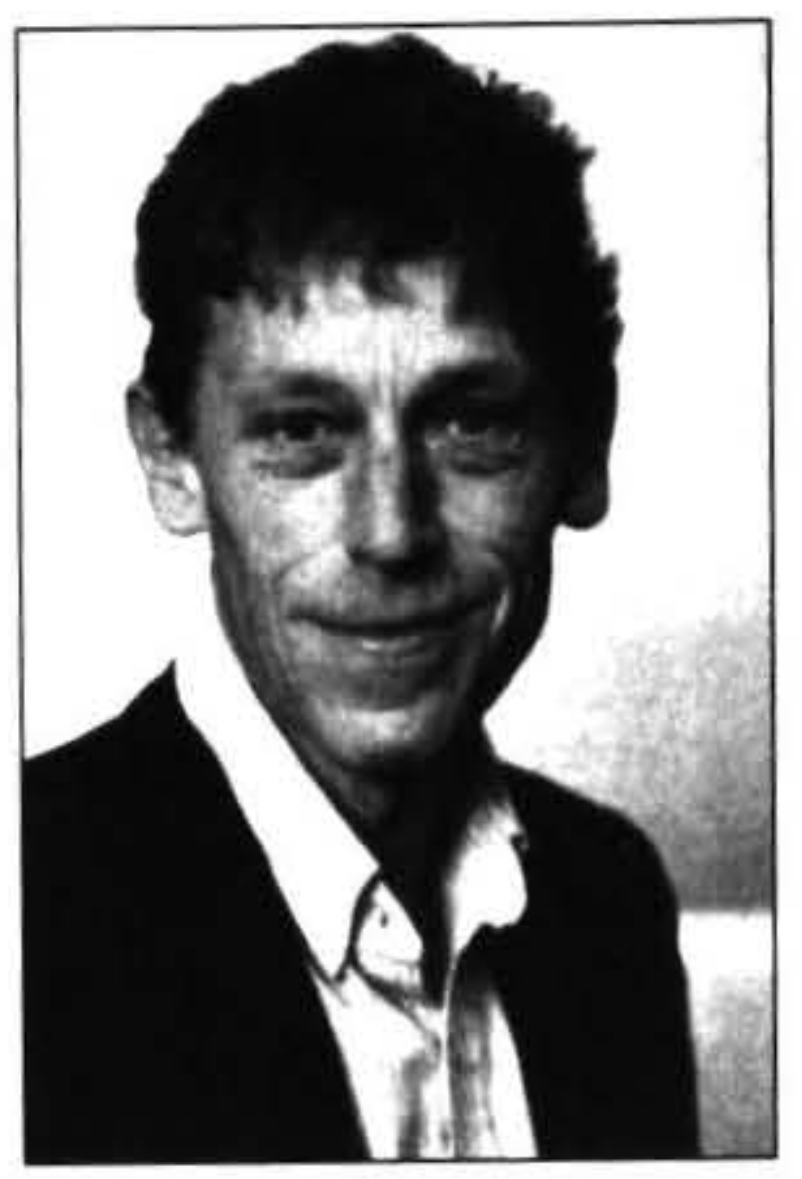

\title{
WHAT CONSTITUTES CAREER SUCCESS? IMPLICATIONS FOR EMPLOYERS AND POLICY MAKERS
}

\author{
Brent Gardiner
}

PhD Student, Department of Commerce, Massey University: Palmerston North

\begin{abstract}
Individuals subjective view of career success varies considerably and will not always align with the goals of employers or policy makers. This paper presents the initial findings of research designed to investigate the subjective perceptions of career success among a sample of younger. New Zealanders who were interviewed as part of the Pathways to Sustainable Employment Project in the Labour. Market Dynamics Research Programme funded by the Foundation for Research Science and Technology: Implications for puhlic policy and career development strategies within emploving organizations are highlighted.
\end{abstract}

\section{Introduction}

"In contrast to the multitude of studies predicting career success. curiously little attention has heen devoted to exploring and understanding the nature of career success" (Heslin. 2005: 376).

The nature of career success has had very little attention from researchers and individuals perceptions of career success have had even less (Arthur. Khapova \& Wilderom, 2005: Gattiker \& Larwood. 1998). There seem to be no published studies that investigate the phenomenon of career success in New Zealand and none internationally that explore the concept among young people. This research is important, for it is likely to inform the facilitation of patinways to and through employment within educational institutions. workplaces and communities, as well as at the socio-political and policy level.

The assumption that people perceive career suceess as 'getting-ahead' underlies career development facilitation and interventions. Yet it is likely that considerable diversity exists in perceptions of career suceess in contemporary society and particularly among young people. As Cloward points out:

"The most silent revolution in the workplace has heen the increasing mumber of serious carcerists who look at the ladder leading to the executive suite - and then look awan: Ther lowe their work. It has a high priority in their lives. The have career plans and carry them out. But they. simply don't want to manage the organization" (1999: I).
Policy and interventions then may need to be tailored differently for a variety of types of career aspirations, not just the 'getting ahead' one.

The lack of research is highlighted by $\operatorname{Kim}(2005: 49)$ who notes how "little literature has empirically explored the relationship between career orientation and career development intervention." In order to examine that relationship, this study firstly investigates whether or not a varicty of subjective views of career success exists. Secondly, it attempts to group or categorise those assorted perceptions. Using data collected as part of the Pathways to Sustainable Employment (PASE) project (see also Dupuis, Inkson and McLaren, 2005).

As an clement of that project a sample of younger people (15-34 year olds) in Aotearoa / New Zealand $(n=66)$ were interviewed about their experience of and views on employment, education and future aspirations. This report cxamines data from the future aspirations section, specifically the participants' perceptions of career success. The analysis groups those career success orientations based on theoretically derived categories then explores the data to ascertain whether the theoretical categories used are adequate to explain the variety of views expressed and to highlight any additional emergent categories.

The following sections examine understandings of the expression "career success" described in the relevant literature detail the method and findings from this exploratory analysis of the current data as it relates to career orientations of younger people in New Zealand and it discusses those results in light of the study's limitations. Implications for further research are discussed. 


\section{Career Success}

The specific literature on career success spans multiple disciplines and this report draws primarily from the management literature as well as the literatures of psychology and sociology.

Career success has been researched significantly since the 1950s but simultaneous study of both subjective and objective career success did not occur until 1988 (Gattiker and Larwood, 1988). These authors argued that it was important to advance our knowledge of the criteria by which individuals judge their own career success. Almost two decades later, Arthur, Khapova and Wilderom (2005) searched 15 empirically oriented and established social science journals for articles concerned with career success. They found 68 articles between 1992 and 2002 after removing 12 that were not directly pertinent to their task of comparing the theoretical assumptions within those articles with existing career theory.

Surprisingly, none of these studies involved collecting the research participants' own view of their measures of career success. This led these authors to ask, "How can subjective careers be adequately researched when the subjective interpretations of career actors themselves....are not allowed expression?" They conclude that "the answer lies in more qualitative research into the subjective criteria that people bring to their own career situations" (2005: 196). In an extension of this search in those same journals through 2005, this author found no published studies that identify those criteria, though a number of studies did operationalise the subjective criteria using measures of job satisfaction.'

Conventional career theories have defined career success primarily from the standpoint of measurable objective factors such as salary or number of promotions (e.g. Gattiker and Larwood, 1988). Therefore, progression, earnings and recognition have been the typical indicators. However, some researchers have explored career success from a subjective perspective. Greenhaus, Callanan and Godshalk (2000), for instance divide the conventional conceptualisation of career into two broad views. The first sees career as structural and the property of an occupation, organisation or both. The second sees career as the property of the individual, that is, the individual's unique pattern of jobs and experiences.

Within the individual perspective, these writers identify three key themes: an 'advancement' theme (career equals progress in status or money); a 'profession' theme (something that doctors and lawyers have, but clerks and machinists do not); and a 'stability' theme (transitions among connected jobs equal a career). They further suggest that the limitations of the definitions contained by these three themes have led to the emergence of less restrictive definitions. These authors then, prefer to define career as "the pattern of work-related experiences that span the course of a person's life" (Greenhaus, Callanan and Godshalk, 2000: 9). They see this definition as not restricted by the limitations associated with the requirements of advancement, professional status or occupational stability. Further, they claim that this definition accounts for both objective and subjective interpretations of career and suggest that it fits well with the changing nature of the world of work. These writers also see the definition to be consistent with the notion of 'boundaryless' career and that of the 'Protean' career. Moreover, they argue that these new conceptualisations of career respect multiple ways for careers to unfold and support the idea of four different career patterns proposed by Driver (1980).

Driver (1980) adopts what he calls a pluralistic approach incorporating four career concepts. These are i) the linear career concept (marked by hierarchical progression through positions with greater authority and responsibility); ii) the expert career (a lifelong commitment to a specific field or occupation with progress marked by increasing expertise and competence); iii) the spiral career (marked by periodic moves between fields, often with a seven to ten year timeframe allowing time for substantial competence to be developed) and iv) the transitory career (movement every three to five years to a very different field or job). This author points out that these four concepts may be combined to form a basis for the description of a variety of forms of career experience. A very different set of motivators drives each of the four concepts. The linear career concept fits the traditional organisational understanding of career, and key motives are the need for power and achievement. Core motives for the expert career are a desire for technical competence along with security and stability. For spiral careers, motives are mainly personal development and creativity whereas for transitory careers, motives are the need for variety and independence achieved by exposure to a constant range of new experiences.

Van Maanen and Schein (1977) investigated individuals' subjective views about their work life and their roles within that. From this inquiry, they developed the concept of a career anchor. They describe a career anchor as an occupational self-concept that both channels and amalgamates the individual's career. Schein (1978) identified five forms of career anchor: managerial competence, autonomy, security, technical/functional competence and entrepreneurial creativity.

Delong (1982) further developed the idea of Schein's (1978) career anchors, though proposed that the term career anchor be replaced by the term career orientation. Career orientation is defined as the capacity to select aspects of an occupation for investment according to one's motivation, interests and capabilities.

Derr (1986) expands Delong's (1982) term 'career orientation' to 'career success orientation'. He states that this refers to the way people define their success at work and that individual perceptions of career success reflect individual values, attitudes and motivation with respect to both work and life in a broader sense. Derr (1986) developed a fundamental set of five dimensions to describe the range of career success orientations that he found among populations of US Navy employees, MBA 
students and multinational executives. The five dimensions that he derived are:

1. Getting ahead: This type reflects the traditional career success type mentioned previously marked by visible metrics of advancement in status, responsibility, salary and authority

2. Getting free: This dimension comprises individuals who pursue personal freedom and autonomy. It includes many entrepreneurs who develop their own service or product and individuals who value independence and freedom from external interruption.

3. Getting secure: This dimension includes persons who value stability, security and predictability at work. They seek long-term job security, are loyal and committed to employers where they feel recognized and value security over advancement.

4. Getting high: Individuals who pursue technical or functional skill development dominate this form. The focus is continued growth in these areas with becoming expert in their chosen area of interest the main aspiration.

5. Getting balanced: This group sees balance between personal and work life as most important. They prefer a work context that respects personal and family life. For them career success means integration with personal and family growth and development.

Baruch (2004) also categorises contemporary measures of career success into five similar core types. The first type has a focus on development of competencies; the second on achievement through lateral rather than upward movement; the third via the security gained by enhancing employability; the fourth with a target of autonomy and entrepreneurship; and the final type aimed at quality of life and work-life balance.

Mayrhofer. Meyer, Steyrer, Maier and Hermann (2004) introduced the concept of career fields. They identify four main career fields. Individual members of the workforee enact their careers within the societal context of these fields. Interviews with a sample of 21 graduates of an Austrian business school found that those within each of these have differing orientations to career success.

In the 'company world' field the success focus is on promotion, getting into top positions, upward mobility and higher salaries. Critical dimensions are cultural capital, particularly in the form of good formal education and social capital, especially relationships with other career actors, with a social network and through collaboration with colleagues. The important contributors to that success are luck and contextual factors. Those in the 'free floating' professional field take more of a progress and development view. Here the view of career success is separated from promotion and focused on selfset objectives and the development of technical and social competencies. Fun and satisfaction at work and attainment of those self-set goals are the measures of success. Interviewees in the 'self employment field see no part played by coincidence, luck or external context and crucial measures of success are repeat customers resulting from development of a good image as opposed to good marketing; being able to deal with the scope and quantity of work; and having no worries about future business or finances. Those in the final field, 'chronic flexibility', rely to some extent on objective measures of success with the money dimension apparent but not so strongly as for the company world field. Internal factors are also emphasised though. Interesting tasks, enjoyment, recognition and satisfied customers are all key measures of success.

Kim (2005) makes a particularly useful effort to consolidate the different interpretations and labels applied to career success namely, career anchors (Schein, 1978), career orientations (Delong, 1982), career concepts (Driver, 1980), career success orientations (Derr, 1986) and measures of career success (Baruch, 2004). Despite the different terms and criteria used at different times, Kim (2005) argues that five types of career orientation may be determined and are common to most of the above. This consolidation of types of career orientation is summarised in Table I which I use later to categorise the data collected in this research. The table not only merges the various typologies from various authors into five types but in the bottom line attempts to describe the criteria which each typology uses. For example, Schein, (1978) describes career anchors as using self-perceived talents as criteria, and career orientation (Delong, 1982) as using self-perceived values.

It should be pointed out here that the consolidation by Kim (2005) includes neither the career themes (Greenhaus, Callanan and Godshalk, 2000), nor success within fields discussed by Mayrhofer et al. (2004). Future work could therefore, expand the consolidation shown in Table I to include these concepts within the five types as well. For example, the advancement theme (Greenhaus et al. 2000) appears to match closely the Type 1 career orientation (Kim, 2005), as does the 'company world' success dimension (Mayrhofer et al. 2004). The current study however, examines the data gathered from participants in New Zealand using the theoretically derived types in their original form as identified by $\mathrm{Kim}$ (2005). 
Table 1: Comparison of theories of career orientation (Kim, 2005, p.50).

\begin{tabular}{|c|c|c|c|c|c|c|}
\hline Types & $\begin{array}{l}\text { Description of common } \\
\text { characteristics }\end{array}$ & $\begin{array}{l}\text { Schein's (1978) } \\
\text { career anchor }\end{array}$ & $\begin{array}{l}\text { Delong's } \\
(1982) \text { career } \\
\text { orientation }\end{array}$ & $\begin{array}{l}\text { Driver's } \\
(1980) \text { career } \\
\text { concept }\end{array}$ & $\begin{array}{l}\text { Derr's (1986) } \\
\text { career } \\
\text { success } \\
\text { orientation }\end{array}$ & $\begin{array}{l}\text { Baruch's (2004) } \\
\text { measures of } \\
\text { career success }\end{array}$ \\
\hline Type 1 & $\begin{array}{l}\text { Advancing up the organizational } \\
\text { hierarchy } \\
\text { Increased responsibility, authority } \\
\text { High status, prestige, income }\end{array}$ & $\begin{array}{l}\text { General } \\
\text { management } \\
\text { competence }\end{array}$ & $\begin{array}{l}\text { Managerial } \\
\text { competence } \\
\text { /identity }\end{array}$ & Linear & Getting ahead & $\begin{array}{l}\text { Self development } \\
\text { competencies }\end{array}$ \\
\hline Type 2 & $\begin{array}{l}\text { Recognised expertise in one area } \\
\text { Excitement to test one's talents and } \\
\text { skills } \\
\text { Continued growth and experience }\end{array}$ & $\begin{array}{l}\text { Technical/ } \\
\text { functional } \\
\text { competence or } \\
\text { pure challenge }\end{array}$ & & Spiral & Getting high & $\begin{array}{l}\text { Lateral } \\
\text { transitions; spiral } \\
\text { movements }\end{array}$ \\
\hline Type 3 & $\begin{array}{l}\text { Stability, predictability, security } \\
\text { Long-term commitment, loyalty }\end{array}$ & Security/stability & Security & Steady-state & $\begin{array}{l}\text { Getting } \\
\text { secure }\end{array}$ & Employability \\
\hline Type 4 & $\begin{array}{l}\text { Maintenance of freedom, avoidance } \\
\text { of restrictions } \\
\text { Creation of own service or product } \\
\text { A variety of different experiences }\end{array}$ & $\begin{array}{l}\text { Autonomy/indepe } \\
\text { ndence or } \\
\text { entrepreneurial } \\
\text { creativity }\end{array}$ & $\begin{array}{l}\text { Autonomy, } \\
\text { creativity or } \\
\text { variety }\end{array}$ & Transitory & Getting free & $\begin{array}{l}\text { Self-management; } \\
\text { entrepreneurship }\end{array}$ \\
\hline Type 5 & $\begin{array}{l}\text { A balanced life } \\
\text { Respect for personal and family life } \\
\text { Flexible time and job sharing }\end{array}$ & Lifestyle & & & $\begin{array}{l}\text { Getting } \\
\text { balanced }\end{array}$ & $\begin{array}{l}\text { Quality of life; } \\
\text { work-family } \\
\text { balance }\end{array}$ \\
\hline $\begin{array}{l}\text { Other } \\
\text { types }\end{array}$ & $\begin{array}{l}\text { Dedication to a cause, making a } \\
\text { contribution to improve the world }\end{array}$ & $\begin{array}{l}\text { Service/dedication } \\
\text { to a cause }\end{array}$ & Service & & & \\
\hline $\begin{array}{l}\text { Criteria } \\
\text { of } \\
\text { typology }\end{array}$ & & $\begin{array}{l}\text { Self perceived } \\
\text { talents, values and } \\
\text { motives }\end{array}$ & $\begin{array}{l}\text { Self- } \\
\text { perceived } \\
\text { attitudes, } \\
\text { values and } \\
\text { needs }\end{array}$ & $\begin{array}{l}\text { Frequency, } \\
\text { time, } \\
\text { direction of } \\
\text { career change }\end{array}$ & $\begin{array}{l}\text { Subjective } \\
\text { definition of } \\
\text { success }\end{array}$ & \\
\hline
\end{tabular}

In addition to the five types classified clearly by Kim (2005), some authors have suggested that there may be additional career orientations that do not fit within the five types. In particular, Kim (2005) has acknowledged this by including in the summary table under 'other types' a 'service or dedication to a cause' type identified by both Schein (1978) and Delong (1982) as an additional career orientation. Delong developed three further types of career orientation in addition to Schein's (1978) original five career anchors. These were identity, service and variety. Van Maanen and Schein (1977) suggest there may be four additional career anchors. These are i) the need for identity; ii) a desire to express affiliative needs and interpersonal talents; iii) a motivation to seek power, influence and control and iv) a need for variety. Schein (1978) modifies the second of these slightly to become the 'service to others' anchor noted by Kim (2005). Schein (1978) also writes that:

\begin{abstract}
".....all of the research so far on career anchors has been done on men and it has been suggested that were women included. one might find that a higher percentage of them would be anchored in the more affiliative, service kinds of career preoccupations because of their prior socialization to be more affiliative" (1978: 170).
\end{abstract}

Consequently, a secondary aim of this research is to examine the data in an exploratory manner for evidence of the existence of any other categories of career success orientation that are in addition to those five core types classified by Kim (2005).

\section{Method}

\section{The Pathways to Sustainable Employment Project (PASE)}

This is a five-year project funded by the Foundation for Research Science and Technology to examine the ways in which young people (15-34) in Aotearoa/New Zealand understand and negotiate various pathways into employment and the effect this has on individuals and communities, as well as the response from employers. There are two core components. The first looks at supply side issues such as the contribution of training and education to various employment options and outcomes, the acquisition of skills and search techniques, utilisation of social networks and the planning and aspirations of individuals (Dupuis, Inkson and McLaren, 2005; Cunningham, Fitzgerald and Stevenson, 2005). The second component scrutinises the strategies and expectations of employers in organising labour supply in the changing labour market (de Bruin, McLaren and Spoonley, 2005; Fitzgerald and McLaren, 2006). Overall the project will inform policy and strategies for achieving the economic goals of sustainable employment and establish the degree of current and potential future alignment between the labour supply and demand for this age group.

\section{Data Collection}

Data collection for the first phase of the former objective was completed using a dual approach. An Aucklandbased research company carried out a computer aided telephone interview (CATI) of a sample of 866 younger people during June and July 2004 . These younger people in four New Zealand geographic regions were selected by 
random digit dialling and surveyed. The four regions were Manawatu-Whanganui, Gisborne-East Coast, Auckland and Wellington. A separate but parallel survey of 100 Māori participants was conducted using the same interview schedule and regions. This sample was chosen from a current longitudinal study of Māori households 'The Best Outcomes for Māori: Te Hoe Nuku Roa'. The interview schedule comprised up to 130 questions based on the participant's employment status. A standard range of questions to determine demographic data was also asked (Dupuis et al. 2005). Furthermore, participants were asked whether they were willing to participate in the second phase of objective one data collection. That resulted in face-to-face interviews of 66 participants.

The interview schedule contained up to 26 questions arranged within four domains. These four areas were perceptions of the world of employment, education, social capital and aspirations. This report examines the data on aspirations. A specific question was included to address the research question being explored here. That question was "If you look back on your career in years to come. and you could then describe it as 'successful', what might it look like?" The question was designed to avoid any predefinition of the term 'career' or of 'successful' allowing the participants to apply their own sense to those. Interviewers explored responses to encourage elaboration of meaning by participants. All interviews took place between June and September 2005. Interviews were transcribed and the data relating to that question was interrogated in the following way.

\section{Data Analysis}

The transcribed data specific to the career success question was analysed using content analysis (Weber, 1985). The Kim (2005) consolidation of categories (Table 1) was used as a basis for this. Each interview transcript was perused and coded for the principal type of career success orientation using the description of common characteristics for each type in that summary to guide the coding. A count of the number of times each type was predominant was performed for the full sample, for each gender and by age group and those counts were converted into percentages. The results section that follows summarises these.

Early in the analysis it was noted that several participants clearly favoured the "service to community or others" success orientation which Kim (2005) had not assigned a separate type to, listing it as "other". For this analysis. that orientation is named 'Type 0 - Service'. Each of the other 5 types were assigned a representative name as follows: Type 1 - Advancement: Type 2 - Competence: Type 3 - Security; Type 4 - Autonomy and Type 5 Balance. Where it was difficult to determine which of two or more types predominated, the first elaborated was coded.

In a commentary on reliability in content analysis, Krippendorf (2004) articulates the sad state of reporting of reliabilities in published research using content analyses. That author concludes that while, "as a critical scholar, I defend the principle of encouraging multiple voices to speak through a text..... mathematical objects such as agreement measures and their use as indices of the reliability of data.....should speak louder than majority opinions, even when published in respectable journals" (2004: 430).

The paper makes a number of recommendations relevant to this analysis with respect to that process. First, that the sample of the data used to test reliability of the full sample must be representative. Second, that multiple coders must work independently using unambiguous and communicable coding instructions. Third, that reliability coefficients of 90 or greater are acceptable to all, though there is debate about adequate levels below that. Finally, that while percent agreement is listed as one of seven recommended statistical formulae for measuring intercoder reliability by Neuendorf (2002: 242), it is considered a liberal measure that loses accuracy as the number of categories increases (Krippendorf, 2004). Therefore, in this research, a colleague coded the data independently from the author. There was agreement on the coding for 60 of the 66 transcripts. This is an interrater reliability of 90.9 percent, which is good based on the recommendations of Neuendorf (2002) and Krippendorf (2004).

The primary approach taken here is a deductive scientific approach using categories drawn from the theoretical literature and decided along with coding rules prior to the examination of the data. However, the study also examines the data inductively for career success orientations that might not fit well with the existing categories and that may suggest the need for a further category. The results of these additional observations are also recorded below.

\section{Results}

The results are shown in Table 2. The gender distribution is skewed with only 17 males and 49 females. This is discussed later with respect to its effect on the results by age group. As Table 2 shows, the sample was also divided into two age subgroups of equal size $(n=33)$ and results summarised for each of these groups.

As can be seen, a portion of participants fell into each of the six categories of career success orientation. For the full sample. Type 2 - competence, was the clear winner with 29.5 percent preferring that perception. These are younger people who see career success as having developed a high level of technical competence and achieved continuing growth and experience. This type was also most favoured by the female portion of the sample ( 31.5 percent) and the younger group (age 15-26) ( 37.7 percent), though the females almost equally chose Type 5 - balance (31.4 percent), which was also the second most preferred group for the full sample and the younger subgroup and second equal for the older subgroup along with Type 0 - service, and Type 2 competence. Type 5- balance, is a preference for 
maintaining lifestyle and work-life balance as the primary determinant of career success.

Inductive examination of the data categorisation and items of disagreement between raters identified one group deemed worthy of further investigation. That group may represent a separate category of career success orientation and is meanwhile tagged 'relationships'. An example is one participant who responded to the career success question as follows:

\begin{abstract}
"One of the things that I've noticed that can make a significant impact in terms of the working environment is just the people that you are with and...sometimes that can be a significant...can have quite $a$ significant impact on your dissatisfaction of the roles to whether you gel with people around you and you're able to connect with them in a way that.... you re able to work in a constructive way".
\end{abstract}

Another example began her response: "...it's the relationships..." Several other transcripts talked about affiliations with others or relationships built, as perhaps their primary determinant of career success. However, this study did not perform an exact count for that category, as it was not coded for. Further analysis or additional research is indicated to examine this.

Striking amongst the findings is that for the full sample, the 'traditional' notion of career success, Type 1 advancement, is well down the list ( 18.5 percent) among this group of New Zealand's younger people, although it is the dominant category among males. That finding for males though, is particularly cautious due to the small number in that sub-sample $(n=17)$. The gender imbalance in the sample is also problematic for the age group findings. While the younger age sub-group is reasonably gender balanced (14 males; 19 females), the older group is not ( 3 males; 30 females). This means that the data in the older group may simply be reflecting the female preferences which it closely matches.

\section{Conclusion}

Overall, this study confirms that younger New Zealanders display individual difference in their conceptualisation of career success and use a variety of criteria as their primary determinant of that. The research shows that the six categories established by Kim (2005), provide a useful framework for grouping the career orientations of this sample but at least one further category, 'relationships', may be necessary in order to establish a suitable framework for exploring the connection between career success orientation and preferred or effective strategies and interventions. Further research is necessary to confirm this.

The sample selection for this research was limited to those accessible by telephone in the first instance. Those actually interviewed were individuals who volunteered and were still contactable a year later and who had provided e-mail contact. Therefore, the sample was not matched demographically to the larger New Zealand population of younger people. While this clearly limits the ability to generalise, it does not limit the evidence that such a distribution exists.

Table 2: Results of data analysis.

\begin{tabular}{|c|c|c|c|c|c|c|c|c|c|c|}
\hline $\begin{array}{l}\text { Success } \\
\text { Orientation }\end{array}$ & $\begin{array}{l}\text { Full } \\
\text { sample } \\
(\mathrm{n}=66)\end{array}$ & $\begin{array}{l}\text { Full } \\
\text { sample } \\
(\%)\end{array}$ & $\begin{array}{l}\text { Male } \\
(n=17)\end{array}$ & $\begin{array}{l}\text { Male } \\
(\%)\end{array}$ & $\begin{array}{l}\text { Female } \\
(n=49)\end{array}$ & $\begin{array}{l}\text { Female } \\
(\%)\end{array}$ & $\begin{array}{l}\text { Younger } \\
\text { group } \\
\text { (age } 27- \\
35 ; n=33 \text { ) }\end{array}$ & $\begin{array}{l}\text { Younger } \\
\text { group } \\
(\%)\end{array}$ & $\begin{array}{l}\text { Older } \\
\text { group } \\
\text { (age } \\
15-26 ; \\
n=33 \text { ) }\end{array}$ & $\begin{array}{l}\text { Older } \\
\text { group } \\
(\%)\end{array}$ \\
\hline $\begin{array}{l}\text { Type } 0 \\
\text { Service }\end{array}$ & 8 & 12.6 & 2 & 13.5 & 6 & 12.5 & 6 & 18.6 & 2 & 6.25 \\
\hline $\begin{array}{l}\text { Type } \\
\text { Advancement }\end{array}$ & 12 & 18.5 & 6 & 36.0 & 6 & 12.5 & 10 & 30.1 & 2 & 6.25 \\
\hline $\begin{array}{l}\text { Type } 2 \\
\text { Competence }\end{array}$ & 19 & 29.5 & 4 & 25.6 & 15 & 31.5 & 6 & 18.6 & 12 & 37.7 \\
\hline $\begin{array}{l}\text { Type } 3 \\
\text { Security }\end{array}$ & 4 & 6.3 & 1 & 7.4 & 3 & 6.25 & 1 & 3.0 & 3 & 10.55 \\
\hline $\begin{array}{l}\text { Type } 4 \\
\text { Autonomy }\end{array}$ & 6 & 9.6 & 2 & 12.2 & 4 & 8.5 & 4 & 12.2 & 2 & 6.25 \\
\hline $\begin{array}{l}\text { Type } 5 \\
\text { Balance } \\
\end{array}$ & 16 & 23.1 & 2 & 12.2 & 14 & 29.3 & 6 & 18.6 & 10 & 31.4 \\
\hline Don't know & 1 & & & & 1 & & 1 & & & \\
\hline
\end{tabular}


The significant finding here is that for 80 percent of this sample of younger people, it is not correct to assume that advancement, income, status and other traditional 'getting ahead' measures of career success are primary drivers. This is consistent with the finding of Dupuis and McLaren (2006) with respect to non-standard work amongst younger workers in New Zealand. They conclude that younger people negotiate pathways through the world of work in a way "very different from the linearity which characterised the employment and life expectations of their parents`generations" (2006: 33).

Policy goals such as that of sustainable employment and the goals of employers tend to be economic ones. There is a probable tension between those goals and the individual goals and aspirations of younger people. Therefore, interventions, strategies and policies that consider the disparate career orientations of individuals in their target populations, yet meet the state's economic goals of sustainable employment and employers' goals of productivity, appear to be necessary.

\section{Acknowledgements}

This research project was carried out as part of the Labour Market Dynamics (LMD) Research Programme that is funded by the New Zealand Foundation for Research, Science and Technology. The Foundation's funding of the research into pathways to sustainable employment is gratefully acknowledged, as is the continuing support of Massey University, the host institution.

The LMD would like to offer sincere thanks to the 66 young people who gave so freely of their time and have provided valuable insights into their perceptions of career success in Aotearoa/New Zealand.

As the recipient of the Labour Market Research Group Doctorate Scholarship, the author of this paper wishes to thank and acknowledge the support of the LMD group.

\section{Notes}

I The journals searched were Academy of Management Journal, Administrative Science Quarterly, Career Development Quarterly. Human Relations, Journal of Applied Psychology, Journal of Career Development, Journal of Management, Journal of Management Studies, Journal of Occupational and Organizational Psychology. Journal of Organizational Behavior, Journal of Social Psychology, Journal of Vocational Bchavior, Organization Science, Organization Studies and Personnel Psychology

\section{Reference}

Arthur, M.B., Khapova, S.N., and Wilderom, C.P.M (2005). Career success in a boundaryless career world. Journal of Organizational Beharior, 26. 177-202.
Baruch, Y. (2004). Managing Careers: Theory and Practice. Essex: Pearson Education.

Cloward, D. (1999). Managing career diversity. Human Resources. Retrieved April 11, 2006, from http://www.afsmi.org/sbusiness/journal/jul99/jul $-002 . h t m$

Cunningham, C., Fitzgerald, E., and Stevenson, B. (2005). Pathways to Emplovment: An Analysis of Young Māori Workers. Research Report No. 2005/3, Labour Market Dynamics Research Programme, Albany and Palmerston North: Massey University.

De Bruin, A., McLaren, E. and Spoonley, P. (2005). Lahour Demand in a Tight Labour Market: A Sunvey of Employers. Research Report No. 2005/2, Labour Market Dynamics Research Programme, Albany and Palmerston North: Massey University.

Delong, T.J. (1982). Reexamining the career anchor model. Personnel, 59, 50-61.

Derr, C.B. (1986). Managing the New Careerists. San Francisco: Jossey Bass.

Driver M.J. (1980). Career concepts and organizational change. In Derr, C.B (ed), Work, Family and the Career: New Frontiers in Theory and Research. NY: Praeger.

Dupuis, A., and McLaren, E. (2006). Non-Standard Work and Young(er) Workers. Research Report No. 2006/1, Labour Market Dynamics Research Programme, Albany and Palmerston North: Massey University.

Dupuis, A., Inkson, K. and McLaren, E. (2005). Pathways to Emplorment: A Studr of the Employment-Related Behaviour of Young People in New Zealand. Research Report No. 1/2005. Labour Market Dynamics Research Programme. Albany and Palmerston North: Massey University.

Fitzgerald, E. and McLaren, E. (2006). Recruitment, Truining and the Mäori Labour Market Supply: An Analysis of Mãori Employers. Research Report No. 2006/2, Labour Market Dynamics Research Programme, Albany and Palmerston North: Massey University.

Gattiker, U.E., and Larwood, L. (1988). Predictor's for managers' career mobility, success and satisfaction. Human Relations, 41, 569-591.

Greenhaus, J.H., Callanan, G.A., and Godshalk, V.M. (2000). Career Management. Orlando, Fl: Harcourt.

Heslin, P.A. (2005). Experiencing career success. Organizational Dinamics, 34, 376-390.

Kim, N. (2005). Organizational interventions influencing employee career development preferred by 
different career success orientations. International Journal of Training and Development, 9, 47-61.

Krippendorf, K. (2004). Reliability in content analysis: Some common misconceptions and recommendations. Human Communications Research, 30, 411-433.

Mayrhofer, W., Meyer, M., Steyrer, J., Maier, J., and Hermann, A. (2004). Thick Descriptions of Career Habitus: Agency and Structure within Career Fields. European Organisation Studies Group, 20th colloquium. Ljubljana, Slovenia.

Neuendorf, K.A. (2002). The Content Analysis Guidebook. Thousand Oaks: Sage.

Schein, E.H. (1978). Career Dynamics: Matching Individual Needs and Organizational Needs. Reading, MA: Addison Wesley.
Van Maanen, J., and Schein, E.H. (1977). Career development. In Jackman, J.R. and Schuttle, J.L. (Eds), Improving Life at Work. Santa Monica: Goodyear

Weber, R.P. (1985). Basic Content Analysis. London: Sage.

\section{Author}

Brent Gardiner

$\mathrm{PhD}$ Student

Department of Commerce

Massey University

Private Bag 11222

Palmerston North

B.D.Gardiner@massey.ac.nz 